\section{Travelling for teeth: characteristics and perspectives of dental care tourism in Hungary}

\author{
A. Österle, ${ }^{1}$ P. Balázs² and J. Delgado ${ }^{3}$
}
IN BRIEF
- Empirically measures the phenomenon of dental care tourism in one of the most prominent destination countries, Hungary.
- Provides information on dental practices, the origin and number of foreign patients treated and the services provided.
- Describes what dentists think about the motivation of their foreign patients travelling to Hungary for dental care.

\begin{abstract}
Background and aim Despite quite lively debates about dental care tourism, scientific studies into the size and the characteristics of the phenomenon remain widely lacking. The present study is the first to measure the phenomenon in one of the most prominent destination countries, Hungary, with a particular focus on the Western Hungarian region and the capital Budapest. Method A questionnaire has been sent to dentists in these regions. The response rate is 25.3\% in Western Hungary and $20.7 \%$ in Budapest. Results According to the survey, patients from neighbouring countries dominate dental care tourism in the border regions of Western Hungary, while Budapest attracts more patients from countries further away. In terms of motivation, dentists regard relative price levels but also service considerations as being of major importance for patients coming to Hungary for dental care. Conclusion The study confirms Hungary as a centre for dental care tourism, attracting patients from bordering countries but also patients travelling longer distances. Price levels have been a major factor making Hungary an international treatment destination. With price differences narrowing down, broader service quality is increasingly emphasised as a selling strategy.
\end{abstract}

\section{INTRODUCTION}

Patient mobility became a prominent concern in health policies in recent years. Internet sites are offering services about treatments abroad, patients are looking for treatments across borders, European Court of Justice decisions have opened up possibilities for the remuneration of medical treatments in other EU member countries and the EU commission attempts to further facilitate patient migration. ${ }^{1,2}$ Dental care is one of the areas where medical care tourism has become particularly prominent. ${ }^{3}$ The importance is well known in professional circles and it is regularly covered in the media. Some welcome it as a market response to costly local provisions, as an expression of the empowered patient or as a sign of increasingly open health care markets. Others emphasise the

${ }^{1 * 3}$ Vienna University of Economics, Institute for Social Policy, Vienna, Austria; ${ }^{2}$ Department of Public Health, Semmelweis University, Budapest, Hungary

${ }^{*}$ Correspondence to: Professor August Österle Email:august.oesterle@wu-wien.ac.at

\section{Refereed Paper}

Accepted 17 February 2009

DOI: 10.1038/sj.bdj.2009.308

${ }^{\bullet}$ British Dental Journal 2009; 206: 425-428 risks involved, in particular concerns of quality, and the difficulties of ensuring adequate local supply coverage. Despite lively debates about dental care tourism, scientific studies into the size and the characteristics of the phenomenon remain widely lacking.

The present study is the first to measure the phenomenon in one of the most prominent destination countries, Hungary. The study focuses on three mainly rural regions in Western Hungary and the capital city of Budapest. Based on a survey among Hungarian dentists, it provides insights into the distribution of foreign patients treated in Hungary, in major treatments provided and the motivations of foreign patients treated in Hungary. The following chapter discusses the context for dental care tourism. After an outline of the study design, the paper then presents the results of the survey. The conclusion puts the findings in a broader perspective and discusses the prospects of dental care tourism.

\section{THE CONTEXT FOR DENTAL CARE TOURISM}

Dental care is often described as different from other health care services, in terms of the care itself and - as a consequence - in the ways in which dental care is organised. ${ }^{4}$ While the demand for urgent health care is unpredictable and occurs suddenly, dental care is less emergency dominated. Not-immediatelytreated dental illnesses mostly do not lead to dramatic health consequences. Also, people tend to consume the same or similar treatments more than once in their lifetime. Many are consuming preventive services on a very regular basis which also informs them about treatments that might become necessary in the near future. Taken together, this gives (potential) patients the possibility to learn from experience, the time to collect and evaluate information, and, hence, the opportunity to plan more freely time and place of consumption as well as provider. And this search for treatment alternatives can also expand across borders. Specific characteristics of dental care have also led to a particular division of public and private burdens in funding dental care, which might provide additional incentives for dental care tourism.

European health care systems are characterised by large levels of public 
funding. Except for some co-payments, access to most health care provisions is free at the point of use. Quite different regulations apply for dental care. Many countries have excluded large parts of dental care from social health insurance or national health service coverage. In other countries, substantial co-payments are required. Austria, one of the major source countries of cross-border dental care in Hungary, for example, provides (at least partial) coverage for specific conservative-chirurgical interventions, removable prosthetic and orthodontic treatments. Specific dental interventions, such as removable prosthetic treatments, may require prior authorisation by the competent insurance institution. ${ }^{5}$ These standard procedures require a co-payment of up to $20 \%$ if provided by contract doctors. These contract doctors, about $65 \%$ of all dentists, are in a contractual relationship with social health insurance funds. If such a standard service is provided by a non-contracted dentist, patients can claim reimbursement from their respective health insurance fund. The reimbursement, however, is limited to $80 \%$ of what would be paid to a contract doctor. In this non-contract sector, the level of fees payable is decided by the dentist, even though there is a list of recommended prices (Autonome Honorarrichtlinien) published annually by the Austrian Dental Chamber. Noncovered services, including implants, crowns or bridges have to be paid for entirely by the patient. ${ }^{5}$ In case of medical necessity only, social health insurance funds can grant subsidies.

The extended financial burden involved with dental care consumption together with the aforementioned characteristics of dental care will make potential patients more likely to search for alternative treatment options. On the one hand, this could involve a search of treatment options in the closer neighbourhood which - for people living in border regions - also includes treatment options just across the border. On the other hand, people could also consider going abroad, if the target country offers cost-effective alternatives. Cost-effectiveness considerations will involve price and quality of the service

Table 1 Inhabitants per dentist in selected provinces/counties in Austria and Hungary $(2006)^{13,15}$

\begin{tabular}{l|l|l|l}
\multicolumn{2}{l}{ Hungary } & Austria \\
\hline Territorial unit & 768 & Territorial unit & inhabitants per dentist \\
\hline Budapest & 1,090 & Vienna & 1,266 \\
\hline Györ-Moson-Sopron & 1,324 & Salzburg & 1,673 \\
\hline Csongrád & 1,479 & Tyrol & 1,687 \\
\hline Vas & 1,762 & Carinthia & 1,967 \\
\hline Baranya & 1,819 & Vorarlberg & 2,001 \\
\hline Hajdú-Bihar & 1,869 & Styria & 2,049 \\
\hline Zala & 2,427 & Upper Austria & 2,340 \\
\hline Bács-Kiskun & $\ldots$ & Lower Austria & 2,342 \\
\hline$\ldots$ & 4,028 & Burgenland & 2,885 \\
\hline Szabolcs-S.-B. & & & \\
\hline
\end{tabular}

Table 2 Origin of foreign patients treated in Budapest and Western Hungary (selected countries)

\begin{tabular}{|l|l|l|l|l|l}
\hline & \% of total foreign patients & \multicolumn{2}{l}{$\%$ of source country } \\
\hline Country & Budapest & $\begin{array}{l}\text { Western } \\
\text { Hungary }\end{array}$ & Total & Budapest & $\begin{array}{l}\text { Western } \\
\text { Hungary }\end{array}$ \\
\hline Austria & $17.4 \%$ & $83.6 \%$ & $67.7 \%$ & $6.2 \%$ & $93.8 \%$ \\
\hline Switzerland & $11.8 \%$ & $8.7 \%$ & $9.4 \%$ & $30.2 \%$ & $69.8 \%$ \\
\hline Germany & $11.8 \%$ & $6.2 \%$ & $7.5 \%$ & $37.9 \%$ & $62.1 \%$ \\
\hline UK & $20.2 \%$ & $0.2 \%$ & $5.0 \%$ & $97.5 \%$ & $2.5 \%$ \\
\hline Romania & $11.3 \%$ & $0.1 \%$ & $2.7 \%$ & $99.0 \%$ & $1.0 \%$ \\
\hline USA & $5.3 \%$ & $0.3 \%$ & $1.5 \%$ & $86.2 \%$ & $13.8 \%$ \\
\hline
\end{tabular}

itself, but also costs and quality from a broader transaction perspective. The latter concerns information costs, costs related to language barriers, broader service quality or reception in the target country. ${ }^{1,2,6}$ Empirical investigation into these determinants is still rare in health care mobility in general ${ }^{7,8}$ and lacking in dental care tourism.

In media coverage, costs and quality are often discussed as the key determinants of dental care tourism. Websites promoting dental care in Hungary argue that top quality treatments in Hungary might cost less than $50 \%$ of the same treatment in Western European countries. While price differences are widely acknowledged, the quality of dental care in Eastern or South Eastern European countries is highly contested. While providers point at high quality provision, others argue that the poor quality is the downside of low prices.
Quality of dental care provision has also been questioned in two earlier studies. Baulig et al. ${ }^{9}$ have studied quality and cost-effectiveness of 60 patients that have received dental care treatment abroad (mostly Eastern Europe and Turkey). The study concludes that just one out of four of these patients received sufficient quality. Only simple dental treatments were evaluated as cost-effective. Major quality concerns were also identified by Joss et al. ${ }^{10}$ studying Swiss patients receiving dental care in Hungary. Also, dental care associations or consumer organisations in Western Europe have raised concerns about the quality. However, they increasingly emphasise the diversity in quality rather than a general low level of quality and the lack of systematic quality assurance. ${ }^{11}$

While the phenomenon of cross-border dental care is widely recognised, 
little is known about the size and the characteristics. A study on cross-border care in the border regions of Austria, Italy and Slovenia has estimated about 45,000 cases of Austrian and Italian patients treated in Slovenia in the years 2000-2002. ${ }^{12}$ For the case of Hungary and Austria, a look at the density of dentists in both countries provides a strong indication that dentists in Hungarian border regions do not just provide the local community (Table 1). In Hungary, the number of inhabitants per dentist ranges between 768 in Budapest and 4,028 in the county of Szabolcs. Apart from the counties with universities, the number of inhabitants per dentist is below 2,000 in most Western counties, notably in Györ-Moson-Sopron $(1,090)$, a region well known as a treatment centre for Austrian patients. In Austria, the number of inhabitants per dentist ranges between 1,266 in Vienna and 2,885 in Burgenland. The latter is the most Eastern Austrian province bordering with the Hungarian counties GyörMoson-Sopron and Vas and close to the county of Zala.

\section{DENTAL CARE TOURISM IN HUNGARY}

The above analysis of dentist density indicates that the Western Hungarian counties and the capital city of Budapest are the most prominent target regions of dental care tourism. Hence, these regions have been selected for a survey among Hungarian dentists in order to identify dimensions, characteristics and perspectives of dental care tourism in Hungary. The questionnaire covered information on dental practices, the origin and number of foreign patients treated, the services provided and on what dentists think about the motivations of their foreign patients travelling to Hungary for dental care. The questionnaire was sent via the Hungarian Medical Chamber to all dentists registered in this corporation (85.4\% of all dentists) and practising in the Western Hungarian region (655 in counties Györ-Moson-Sopron, Vas and Zala) and in Budapest $(1,966)$ by December 2007. ${ }^{13}$ Responses from $25.34 \%$ and $20.65 \%$ of these dentists, respectively, have been included for further analysis. In Buda- pest, $40 \%$ of respondents hold a contract with the National Health Insurance Fund (NHIF), 60\% are working for private patients only. In Western Hungary, about half of all respondents hold a contract with NHIF.

According to the survey, almost two thirds of all practices in Western Hungary are providing services to foreigners. The respective proportion is below $50 \%$ in Budapest. The differences become more pronounced when looking at the income from services provided to foreign patients compared to total income. In Budapest, only a few practices earn more than $20 \%$ of their total income from serving foreign patients. In Györ-Moson-Sopron, 42\% of all practices responding to the respective question report that more than $60 \%$ of their income is from services provided to foreign patients.

In an additional step, the survey made an attempt to estimate the number of foreign patients treated in the Hungarian target regions. If the data collected are linearly scaled up allowing for nonrespondents, our study suggests a minimum number of 104,038 foreign patients travelling to Hungary in 2006 for dental care $(78,983$ in the border regions of Western Hungary and 25,055 in the capital of Budapest). These figures have to be seen as an absolute minimum level of foreign dental care patients treated in Hungary, because they are based only on the data of responding dentists. Uninterested or even hiding providers might have treated proportionally even more foreign patients.

In terms of country background, the vast majority of those travelling to Western Hungary are Austrians (83.6\%), followed by patients from Switzerland (8.7\%) and Germany (6.2\%) (Table 2). This is not surprising, given the geographical proximity of Hungarian dental target regions and the aforementioned countries of origin. Additionally, Western Hungarian dentists and practices are also known for having profound knowledge of the German language thus facilitating cross border patient mobility. In the case of Györ-Moson-Sopron, Vas and Zala, patients from the UK, Ireland and the US only played a secondary role so far. The data suggest that in these provinces it is just a few larger practices where patients from these countries concentrate.

As indicated by Table 2, a different pattern is observable in the case of Budapest. In fact, the provenance of foreign dental care patients shows a much more heterogeneous distribution compared to Western Hungary. About one fifth of foreign patients treated in Budapest are from the UK followed by Austrians (17.4\%), Germans (11.8\%) and Swiss customers $(11.8 \%)$. In relative terms, $97.5 \%$ of UK dental patients in the target regions are treated in Budapest. The respective figure is $37.9 \%$ for Germany and 30.2\% for Switzerland. In the Austrian case, just 6.2\% are treated in Budapest. According to the survey, Romania, with a large population of ethnic Hungarians (1.5 million), is another important source country. However, as the survey did not cover the Eastern border regions with Romania, further analysis would be required to estimate the extent of Romanian citizens treated in Hungarian practices.

When asked about the three most common services required by foreign patients, both in Budapest (88.5\%) and in the Western border regions (95.2\%) a vast majority of dentists named fix dental replacements. Fillings $(71.2 \%$ and 39.7\%), implants (33.7\% and 44.4\%) and partial denture procedures $(18.3 \%$ and $58.7 \%$ ) are other common treatments provided for foreign patients.

The size and the design of the study did not allow an in-depth analysis of determinants for patients' decisions to travel to Hungary for dental care. But, the survey has asked dentists about their view on why Austrian patients were seeking dental care treatment in Hungary. Generally speaking, the results confirm the multidimensionality in the determinants of cross-border patient mobility as assumed by more conceptual studies ${ }^{2,6,14}$ and indicated by other empirical surveys on patient mobility in Europe. ${ }^{12}$ Our survey suggests, at least for the Austrian case, that monetary as well as non-monetary factors have an impact on the existence and extent of dental care tourism.

The vast majority of dentists, both in Budapest (89.5\%) and in the Western counties (95.1\%), regard lower prices as 
a key determinant for dental care tourism (Table 3). Additionally, service considerations are a major argument for about half of all dentists in both parts of Hungary. Two additional motivations, 'friendly environment' and 'geographical proximity', are more important for Western Hungary compared to Budapest. Not surprisingly, proximity is an argument for people living in border regions. Also plausible is that a friendly reception can be a stronger incentive for patients living in the closer neighbourhood, where patients might regularly visit dentists across the border for more minor treatments. Also, a friendly environment becomes a decisive factor when cost differences are not too pronounced. While our study has only been investigating the perspective of dentists, additional studies are needed to analyse how dental care patients' decisions are determined.

\section{CONCLUSION}

This is the first study confirming by statistical methods that dental care tourism has developed into a significant health sector phenomenon in Central Europe, with large numbers of patients travelling across regional borders, but also patients travelling from more distant source countries to Hungary. Price differences have been and are still playing a key role in determining the decisions of patients to travel abroad for teeth. The demand for dental care, but also the development of supply capacity in Western Hungary and the focus on the needs of foreign patients has led to the establishment of a transnational dental care cluster. The question is whether such centres can keep their prominent role when price differences are narrowing down. The data suggest that Hungarian dentists in the target regions in fact attempt to emphasise service and a friendly reception, a diversity of information tools and quality assurance as key elements of their selling strategy.

In recent years, there is increasing debate in Europe on how to facilitate the mobility of patients. ${ }^{1}$ Dental care in Hungary is an example for spontaneous developments grown much earlier from the bottom without particular

Table 3 Determinants of dental care tourism, the dentists' perspective

\begin{tabular}{l|l|l}
\hline Determinants & $\begin{array}{l}\text { Budapest } \\
(\mathrm{N}=381)\end{array}$ & $\begin{array}{l}\text { Western Hungary } \\
(\mathrm{N}=162)\end{array}$ \\
\hline Low prices & $89.5 \%$ & $95.1 \%$ \\
\hline Better service & $53.5 \%$ & $51.9 \%$ \\
\hline Friendly environment & $29.7 \%$ & $45.7 \%$ \\
\hline Geographical proximity & $18.9 \%$ & $24.1 \%$ \\
\hline Better quality & $18,6 \%$ & $17.3 \%$ \\
\hline Multiple answers allowed & & \\
\hline
\end{tabular}

incentives or bilateral agreements facilitating these movements. On the one hand, this is a result of the specific characteristics of dental care. ${ }^{3}$ Except for urgent treatments or when patients already suffer from toothache, consumers have the opportunity, the time and the interest to collect information and to compare alternative provisions. Also related to dental care characteristics, in the decision-making process, consumers do not just recognise medical arguments but will also take into account price, waiting time or broader service quality.

From a general health perspective, current European Union attempts to facilitate cross-border health care might further open up opportunities for patients to travel to other countries and for practices to attract foreign patients. Given the non-transferability of health services, this could also become a more prominent alternative to the migration of providers. For countries and regions, where there is currently a lack of health service coverage or where many doctors are emigrating, the inflow of patients could allow for more attractive practice options and help to develop more adequate supply structures. Such opportunities will differ according to the particular health service characteristics. But, the case of dental care tourism in Hungary confirms that regions can develop into health care clusters gaining importance beyond the national level and beyond border regions.

This article is based on a project on mobility in health care. Financial support for this project from the Anniversary Fund of the Austrian National Bank (OeNB, Grant No. 12164) is gratefully acknowledged.
. Legido-Quigley H, Glinos I, Baeten R, McKee M. Patient mobility in the European Union. Br Med J 2007; 334: 188-190.

2. Rosenmöller M, McKee M, Baeten R. Patient mobility in the European Union - learning from experience, 1st ed. Copenhagen: European Observatory of Health Systems and Policies, 2006.

3. Turner L. Cross-border dental care: 'dental tourism' and patient mobility. Br Dent J 2008; 204: 553-554.

4. Sintonen $\mathrm{H}$, Linoosmaa I. Economics of dental services. In Culyer A J, Newhouse J P (eds). Handbook of health economics, 1st ed. pp 1251-1296. Elsevier Science, 2000.

5. Kravitz A, Treasure E. Manual of Dental Practice. Dental Liaison Committee in the EU. [document on the Internet]. 2008 [cited 16 January 2009] Available from: http://www.eudental.eu/index. php? ID = 35918

6. Österle A. Health care across borders. Austria and its New EU neighbours. J Eur Soc Policy 2007; 17: 112-124.

7. France G. Cross-border flows of Italian patients within the European Union: an international trade approach. Eur J Public Health 1997; 7: 18-25.

8. Starmans $B$, Leidl $R$, Rhodes $G$. A comparative study on cross-border hospital care in the Euregio Meuse Rhine. Eur J Public Health 1997; 7: 33-41.

9. Baulig C, Weibler-Villalobos U, Körner I, Krummenauer F. Evaluation von Ergebnisqualitat und Kosteneffektivitat zahnärztlichprothetischer Versorgungen im (Nicht-EU-) Ausland. Dtsch Zahnarztl Z 2004; 59: 230-235.

10. Joss $A$, Christensen M M, Jakob S, Oberholzer $G$, Lang N P. Qualität von zahnärztlich-prothetischen Versorgungen im Vergleich (Schweiz/Ausland, speziell Ungarn). Acta Med Dent Helv 1999; 4: 77-85.

11. Konsument: Zahnbehandlung in Ungarn. Pannonisches Roulette. Konsument 2005; 3: 10-12.

12. Albreht T, Pribaković Brinovec R, Stalc J. Crossborder care in the south: Slovenia, Austria and Italy. In Rosenmöller M, McKee M, Baeten R(eds). Patient mobility in the European Union - learning from experience, 1st ed. pp 9-22. Copenhagen: European Observatory of Health Systems and Policies, 2006

13. Balázs P. A magyar fogorvos társadalom testületi válasza a kötelezö kamarai tagság megszüntetésére (with summary in English). Fogorv Sz 2007; 100: 159-166.

14. Glinos I, Baeten R. A literature review of crossborder patient mobility in the European Union. [document on the Internet]. 2006 [cited 16 January 2009] Available from: http://www.ose.be/files/ health/WP12_lit_review_final.pdf

15. Statistik Austria: Personal im Gesundheitswesen [document on the Internet]. 2009 [cited 16 January 2009] Available from: http://www.statistik.at/web de/statistiken/gesundheit/gesundheitsversorgung/ personal_im_gesundheitswesen/index.html 